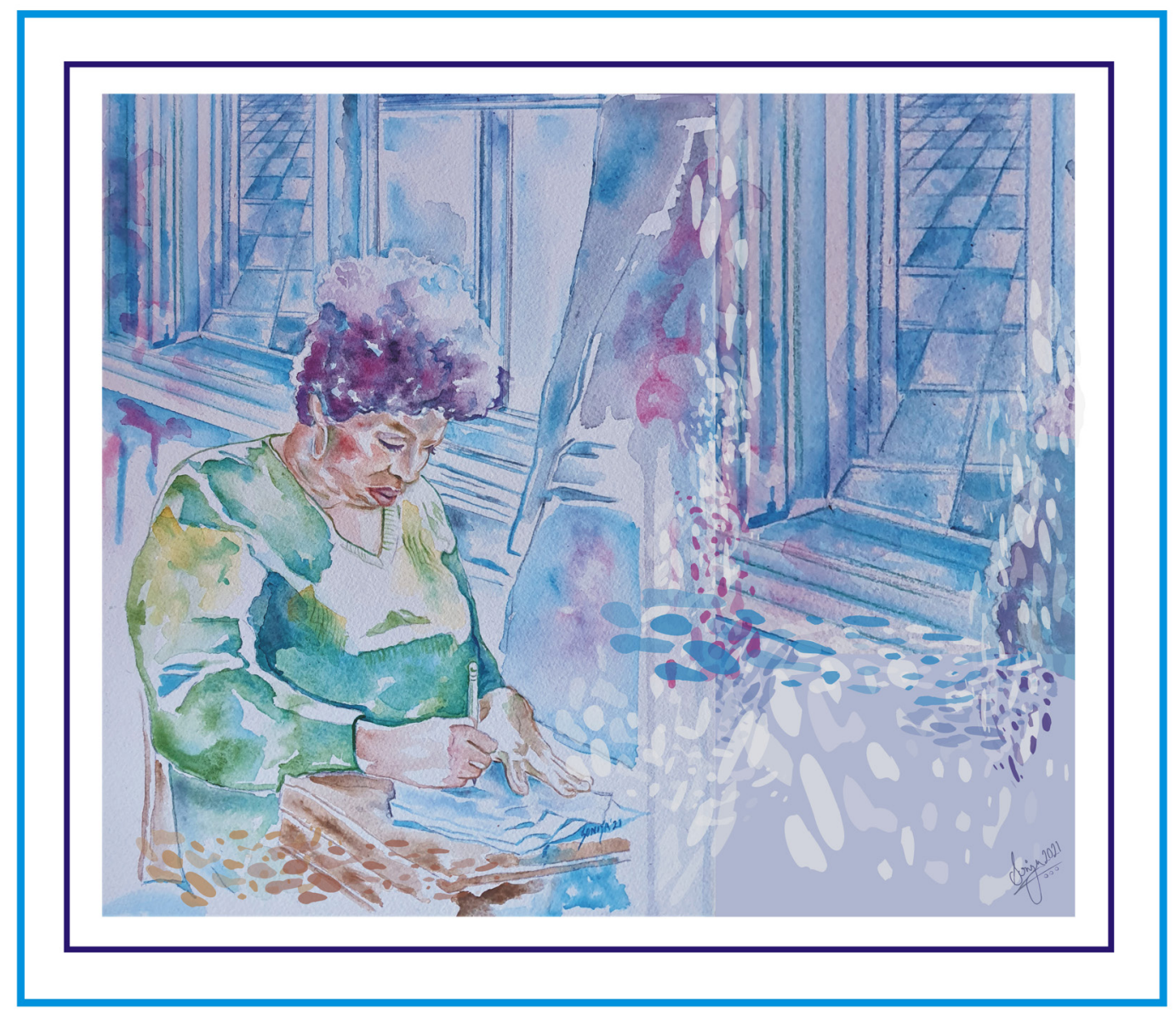

\title{
Soledad Creativa con Toni Morrison
}

\section{Reflexión}

En el silencio de una soledad impuesta, encuentro las palabras, antes elusivas. Mi lienzo opaco se ilumina, dejando a un lado la muerte del aislamiento.

En lo profundo de mi alma se enciende una luz, una antorcha de plumillas y pinceles, y ya no estoy sola.

El encierro impuesto deja de herirme, mi desesperación se desvanece, reemplazada por los flujos de líneas azules, malvas y rosas.

\section{Autora}

Soniya Amritlal Patel es una artista e investigadora indo británica residente en Madrid. Doctora en estudios postcoloniales, feminismo y arte contemporáneo de India, estudió bellas artes en la Universidad de Nigeria. Ha contribuido a diversas publicaciones y ha expuesto ampliamente. (www.soniyaamritpatel.com)

Arteterapia: papeles de arteterapia y educación artística para la integración social. Monográfico: Las miradas del arte y el arteterapia en tiempos de la Covid19. ISSN-e: 1988-8309 https://dx.doi.org/10.5209/arte.75931 